\title{
Citra Tokoh Sutik dalam Novel Burung Burung Migran Karya Miranda Harlan dan Sutik AS (Kajian Perspektif Feminisme)
}

\author{
Yuliana Fitrianita Kurnia ${ }^{1}$ Harun Ahmad ${ }^{2}$ \\ IKIP Budi Utomo Malang
}

\begin{abstract}
Abstrak: Novel burung-burung migran diciptakan oleh Miranda Harlan dan Sutik AS mengungkapkan kekuatan perempuan dengan cara dia berurusan dengan betapa sulitnya kehidupan bisa. Karakter sutik yang digambarkan dalam novel ini cocok untuk dilihat dari sudut pandang feministik. Oleh karena itu, studi ini diambil, Selain menjelaskan struktur novel, juga untuk menjelaskan, khususnya, gambaran karakter Sutik dalam novel burung-burung migran dilihat dari sudut pandang feminis. Objek yang dipelajari dari novel ini adalah tentang struktur novel itu sendiri, yang terbagi menjadi tiga elemen; latar belakang, karakterisasi, dan Plot cerita. Namun, karakterisasi Sutik dianalisis melalui tiga aspek yang berbeda, secara fisik, psikologis, dan sosial. Studi literatur burung-burung migran ini menerapkan metode kualitatif deskriptif dengan modus ideologis feministik pendekatan kritikus literatur. Menggunakan sumber bentuk tertulis, diambil dari novel "burung-burung migran" oleh Miranda Harlan dan Sutik AS. Data dikumpulkan melalui sebuah studi literatur dan dianalisis melalui beberapa langkah, yang (a) pemilihan data, (b) identifikasi dan Klasifikasi data, (c) interpretasi data, yang akhirnya berakhir dengan gambar kesimpulan. Hasil penelitian menunjukkan bahwa struktur novel, "burung-burung migran", yang dianggap dari latar belakang, memiliki sembilan pengaturan tempat, delapan pengaturan waktu, dan lima pengaturan sosial. Ini memiliki sepuluh karakter, yang menonjol dalam cerita, juga memiliki 55 karakter lain. Dianggap dari plotting, ia menggunakan kembali-dan-sebagainya aliran ide, yang memiliki empat klimaks dari berbagai tahap. Namun, citra karakter Sutik dibagi menjadi tiga aspek yang berbeda, mereka adalah salah satu aspek fisik, lima aspek psikologis, dan aspek sosialnya terbagi menjadi tiga aspek dalam keluarga dan tiga orang lainnya dalam masyarakat. Saran saya adalah bahwa studi lain perlu dilakukan terhadap novel ini, dari perspektif gynocritics feministis. Selain itu, dalam rangka mencapai hasil terbaik dalam melakukan studi literatur feminis, pilihan yang tepat dari sumber data adalah suatu keharusan.

Kata Kunci: novel, fenimisme, citra tokoh.
\end{abstract}

\section{The Image Of The Sutik In The Migrant Bird Novels By Miranda Harlan And AS Sutik AS (Review Of Feminism Perspective)}

Abstract: The novel Burung-Burung Migran created by Miranda Harlan and Sutik AS reveals female power in a way she deals with how hard a life could be. Sutik's character which portrayed in the novel is suitable to be viewed from feministic 
perspective. Therefore, the study was taken, besides explaining the structure of the novel, also to explain, in particularly, the image of Sutik's character in the BurungBurung Migran's novel viewed from feministic perspective. The object studied from this novel was about the structure of the novel itself, which divided into three elements; the background, characterization, and the plot of the story. However, Sutik's characterization was analyzed through three different aspects, physically, psychologically, and socially. This literature study of Burung-Burung Migran applies descriptive qualitative method with feministic ideological mode of literature critics approach. It uses a written form source, taken from the novel "Burung-Burung Migran" by Miranda Harlan and Sutik AS. The data is collected through a literature study and analyzed through several steps, which are (a) data selection, (b) identification and classification of the data, (c) data interpretation, which finally ends in the drawing of conclusion. The result of the study shows that the structure of the novel, "Burung-Burung Migran", considered from the background, has nine place settings, eight time settings, and five social settings. It has ten characters, which are prominent in the story, also has fifty-five other characters. Considered from the plotting, it uses back-and-forth flow of ideas, which has four climaxes of different stages. However, the image of Sutik's character is divided into three different aspects, they are one physical aspect, five psychological aspects, and her social aspect is subdivided into three aspects of hers in the family and three others in the society. My suggestion is that another study needs to be conducted towards this novel, from feministic gynocritics perspective. In addition to that point, in order to achieve the best result in conducting a feminist literature study, the appropriate choice of data source is a necessity.

Keywords: the structure of novel, the image of Sutik, feminism perspective.

\section{PENDAHULUAN}

Novel Burung-Burung Migran karya Miranda Harlan dan Sutik AS yang diterbitkan pada tahun 2011 oleh Qanita, Jakarta Selatan merupakan novel yang menarik. Isi novel itu mencerminkan perwujudan "kemerdekaan" sepanjang hayat yang dimiliki seorang wanita tanpa merasa terganggu oleh konstruksi norma dan ikatan hukum dalam sistem sosial. Pada dasarnya, pribadi-pribadi yang sudah merdeka sejak dalam jiwa dan pikiran adalah pribadi-pribadi yang tidak kenal takut dan takluk, bahkan pada rasa takut itu sendiri (Harlan dan Sutik AS, 2011:2). Kehadiran tokoh wanita yang dimaksud tersebut tertuang dalam diri tokoh Sutik sebagai contoh pribadi yang telah mengibarkan bendera merdeka yang berakar pada jiwa dan pikiran.

Dilihat dari judulnya, Burung-Burung Migran, kata burung-burung ini bukanlah makna yang sebenarnya. Kata burung-burung yang "migran" tersebut merujuk pada para TKI yang mengais rejeki di Malaysia. Mereka meninggalkan tempat kelahiran dan mencari sumber penghasilan untuk keberlang-sungan hidup dengan berpindah tempat seperti yang dilakukan burung-burung yang dikenal kerap berpindah hunian 
untuk mendapatkan makanan. Perilaku burung-burung migran dalam novel ini terepresentasikan oleh tokoh Sutik dan kawan-kawannya.

Fenomena TKW (Tenaga Kerja Wanita) sudah akrab di telinga masyarakat Indonesia. Sebutan TKW lebih familiar dibandingkan sebutan TKI. Hal ini dikarenakan jumlah tenaga kerja wanita yang lebih signifikan dibandingkan jumlah tenaga kerja pria Indonesia yang merantau ke luar negeri. Program pengiriman tenaga kerja keluar negeri memang sudah dicanangkan sebagai program resmi oleh pemeritah semenjak tahun 1976. Semenjak itu pula, para TKI atau TKW sah menjadi penyumbang devisa negara. Namun sayangnya, fakta tersebut nampak tidak adil dan berbanding terbalik dengan pelayanan dan perhatian yang semestinya diberikan pemerintah kepada para pahlawan devisa tersebut. Cerita kehidupan mereka di tanah rantau lebih diwarnai dengan cerita pilu yang menyayat hati, mulai dari penyiksaan sadis yang mereka terima dari atasan sampai kisah pembunuhan dan macam-macam pelanggaran HAM lainnya. Selain itu, tidak banyak yang tahu bagaimana perjuangan para TKI untuk sampai ke negeri orang, bagaimana mereka tetap berusaha menunjukkan rasa cinta yang besar terhadap negeri kelahirannya sekalipun dicemooh, atau bagaimana sebenarnya pergolakan yang kerap mereka rasakan di negeri orang demi mendongkrak ekonomi keluarga dan ekonomi tanah air tercintanya. Novel Burung-Burung Migran menjadi pilihan yang menarik karena mengangkat fenomena sosial yang dekat dengan masyarakat Indonesia. Selain itu, novel karya Miranda Harlan dan Sutik AS tersebut merupakan novel yang mengandung unsur sejarah, sosial, dan juga moralitas.

Sekalipun demikian, pendekatan feminisme ragam ideologis merupakan pendekatan yang akan digunakan dalam penelitian ini. Alasan memilih pendekatan feminisme yaitu karena pendekatan feminisme merupakan pendekatan yang paling dekat untuk dijadikan sebagai pisau bedah mengingat besarnya keterlibatan dan sorotan terhadap tokoh perempuan. Sugihastuti (2009) menyatakan dalam ilmu sastra, feminisme berhubungan dengan konsep kritik sastra feminis, yaitu studi sastra yang mengarahkan fokus analisis kepada wanita. Feminisme merupakan pendekatan yang mendukung ditegakkannya keadilan dalam memandang wanita dan pria sebagai makhluk yang setara, tanpa dominasi dan subordinasi. Pendekatan kritik sastra ragam ideologis melibatkan wanita, khususnya kaum feminis, sebagai pembaca. Pembaca dilibatkan untuk fokus melihat bagaimana citra serta stereotip wanita dalam suatu karya sastra (Sugihastuti, 2009:138).

Perspektif feminisme mengenai wanita ideal sekiranya tertuang dalam diri tokoh Sutik. Wanita ideal yaitu wanita yang tidak semata-mata dilihat dari segi fisik, perawan atau tidak perawan, melainkan wanita yang berdaya dan sanggup berdiri di atas pijakan kaki sendiri. Sehingga sosok wanita tersebut dapat menyampaikan alternatif yang menjadi pilihannya, tidak hanya sekedar pasrah dengan keadaan, 
menurut atau menerima citra laki-laki yang menguasai hubungan sosialnya dengan wanita baik dalam keluarga maupun dalam masyarakat (Srinthil, 2005:115). Kehadiran novel Burung-Burung Migran sesungguhnya menambah kekuatan penyuaraan kaum feminisme. Tokoh Sutik sebagai tokoh utama dalam novel itu digambarkan sebagai wanita yang sama sekali tidak menggantungkan hidupnya pada laki-laki. Perilakunya sejalan dengan kehendak feminisme yang selalu berusaha keras menunjukkan bahwa wanita bukanlah makluk yang lemah dan pantas diperlakukan sebagai yang termarginalkan seperti prilaku tokoh wanita dalam novel-novel terkenal Ronggeng Dukuh Paruk, Gadis Pantai, Cantik itu luka, Siti Nurbaya, dan sebagainya.

Novel Burung-Burung Migran karya Miranda Harlan dan Sutik AS menarik dari segi citra diri Sutik dikaji dalam perspektif feminisme. Oleh karena itu, berdasarkan deskripsi di atas permasalahan pokok penelitian ini, adalah (1) Bagaimanakah struktur novel BBM karya Miranda Harlan dan Sutik AS?; (2) Bagaimanakah citra tokoh Sutik dalam novel $B B M$ karya Miranda Harlan dan Sutik AS dalam perspektif feminisme? Berdasarkan permasalahan pokok yang ingin diteliti tersebut, tujuan penelitian ini adalah untuk (1) menjelaskan struktur novel $B B M$ karya Miranda Harlan dan Sutik AS yang meliputi: (a) latar dan pelataran, (b) tokoh dan penokohan, (c) alur dan pengaluran; dan (2) mendeskripsikan citra tokoh Sutik dalam novel Burung-Burung Migran karya Miranda Harlan dan Sutik AS dikaji dalam perspektif feminisme yang meliputi (a) citra Sutik dalam aspek fisik, (b) citra Sutik dalam aspek psikis, dan (c) citra Sutik dalam aspek sosial yang dijelaskan lagi atas citra Sutik dalam keluarga dan citra Sutik dalam masyarakat.

\section{METODE}

Penelitian ini merupakan penelitian deskriptif kualitatif dengan pendekatan kritik sastra feminis ragam ideologis. Deddy Mulyana (Siswantoro 2010:47) mengatakan istilah lain yang identik dengan pendekatan yaitu perspektif, kerangka konseptual, kerangka pemikiran, strategi intelektual, paradigma dan teknik interpretasi. Pendekatan merupakan media untuk menangkap realita atau fenomena sebelum melakukan analisis terhadap sebuah karya. Pendekatan dalam penelitian ini yaitu pendekatan kritik sastra feminis ragam ideologis. Saraswati (2003:161) menjelaskan kritik sastra feminis ideologis melibatkan wanita, khususnya kaum feminis sebagai pembaca. Yang menjadi pusat perhatian pembaca adalah citra serta stereotip seorang wanita dalam karya sastra. Stereotip merujuk pada konsepsi mengenai sifat kaum wanita berdasarkan prasangka yang subjektif dan tidak tepat.

Data merupakan sumber informasi dan sebagai bahan untuk dianalisis. Sumber data merupakan subjek penelitian darimana data diperoleh. Berdasarkan hal tersebut, data penelitian ini adalah data tertulis yang berbentuk sebuah teks yang menunjukkan citra diri Sutik dalam aspek fisik, aspek psikis, dan citra Sutik dalam aspek sosial. 
Teks-teks tersebut berupa dialog, monolog, atau paparan. Sumber data penelitian ini diambil dari novel BBM karya Miranda Harlan dan Sutik As. Novel tersebut diterbitkan oleh Qanita pada tahun 2011. Teknik pengumpulan data dilakukan dengan mengikuti tahap-tahap: (1) pembacaan secara cermat sumber data, (2) membaca secara berkesinambungan dan berulang-ulang sumber data, (3) setelah membaca berulang-ulang, selanjutnya menentukan bagian dari sumber data yang akan diangkat menjadi data dan dikaji lebih lanjut. Teknik analisis data dilakukan dengan langkahlangkah: (1) membaca kembali data untuk menyeleksi dan menandai dengan tanda tertentu, (2) mengidentifikasi dan mengelompokkan data sesuai dengan butir masalah penelitian, (3) data-data yang telah didapat tersebut ditafsirkan kembali demi menemukan kepaduan, kesatuan, dan hubungan antardata agar diperoleh pengetahuan yang utuh tentang citra tokoh Sutik dalam novel Burung-Burung Migran.

\section{HASIL DAN PEMBAHASAN}

\section{Struktur Novel Burung-Burung Migran Karya Miranda Harlan dan Sutik AS}

Kajian terhadap novel Burung-Burung Migran dilakukan dengan mengkaji dua hal dalam novel tersebut, yaitu struktur novel dan citra tokoh Sutik dalam novel Burung-Burung Migran dalam perspektif feminisme.

Struktur novel Burung-Burung Migran akan disingkap dari segi latar dan pelataran, tokoh dan penokohan, serta alur dan pengaluran. Struktur latar dan pelataran adalah struktur yang berkenaan dengan pengertian tempat, bagaimana hubungan waktu, dan lingkungan sosial tempat terjadinya peristiwa-peristiwa yang diceritakan (Abrams dalam Nurgiyantoro 2010:216). Di dalam novel BBM karya Miranda Harlan dan Sutik AS ini juga menampilkan tiga jenis latar yaitu latar tempat, waktu, dan sosial. Latar tempat mengacu pada lokasi terjadinya peristiwa yang dikisahkan dalam sebuah karya fiksi. Nurgiyantoro (2010:227) mengemukakan bahwa latar tempat dalam sebuah novel biasanya meliputi berbagai lokasi. Lokasi tersebut berpindah-pindah sejalan dengan perkembangan plot dan tokoh. Dalam novel karya Miranda Harlan dan Sutik AS tersebut, tersaji beberapa latar tempat yang berupa nama negara, daerah, atau lokasi tempat suatu peristiwa yang disebut dalam cerita. Latar tempat yang dominan dalam novel $B B M$ yaitu Tretes dan Malaysia. Sementara latar tempat lain yaitu, Malang, Surabaya, Andalas, Pinang, dan Singapura.

Latar waktu berkaitan dengan perbincangan tentang "kapan" terjadinya peristiwa-peristiwa yang diceritakan dalam sebuah karya fiksi. Dalam novel $B B M$, tersaji latar waktu yang tidak disebutkan secara lugas akan tetapi hanya dijelaskan secara tidak langsung yakni tanpa penyebutan angka tahun. Salah satunya yaitu latar waktu yang mengarah pada masa kecil Sutik hingga ia dinikahkan pada usia 13 tahun. Selama periode tersebut, berbagai macam perasaan dirasakan Sutik. 
Dalam novel $B B M$, latar sosial yang digambarkan cukup banyak senada dengan banyaknya latar tempat yang dicantumkan. Latar sosial itu mencakup warga desa Prigen Tretes, di mana Sutik lahir dan tumbuh besar. Mereka tergolong masyarakat yang tidak memandang penting kehidupan beragama. Masyarakat tempat Sutik dilahirkan terbiasa memiliki pola pemikiran yang masih dominan dan konvensional.

Miranda Harlan dan Sutik AS melibatkan 55 tokoh dalam novelnya yang berjudul Burung-Burung Migran. Lima puluh lima tokoh tersebut ditempatkan pada gradasi yang berbeda dalam novel itu. Pada pembahasan ini hanya ada sebelas tokoh yang akan dibahas dari lima puluh lima tokoh tersebut. Kesebelas tokoh tersebut dianggap sebagai tokoh yang turut ambil andil dalam menggerakkan setir alur cerita dan perwatakan tokoh Sutik. Berdasarkan perwatakannya, penokohan yang akan dibahas dalam kajian ini terdiri atas tokoh protagonis dan tokoh antagonis, tokoh sederhana dan tokoh bulat dan berdasarkan berkembang dan tidaknya perwatakan tokoh dibedakan atas tokoh statis dan tokoh berkembang. Kesebelas tokoh yang dimaksud akan dibicarakan secara berurutan yaitu tokoh Sutik, Yamin, Sulis, Mbah Tarjo dan Pak Mo, Chow dan Tessa, Sumiati, Bang Man, Tuti, dan Milah.

Alur yang terdapat pada novel $B B M$ memotret perjalanan hidup Sutik sejak ia kanak-kanak hingga masa ia dikenal sebagai aktivis pemberdayaan wanita. Lika-liku kehidupan sejak kecil yang kerap membawanya pada rupa peristiwa yang menuntut keberanian menentukan sikap, menyebabkan Sutik menjadi wanita tangguh dan berpotensi memajukan wanita-wanita lain di sekitarnya.

Miranda Harlan dan Sutik AS memilih alur yang tergolong dalam jenis alur majemuk, karena novel tersebut tidak hanya mengandung alur utama saja tetapi juga terdapat penambahan subplot. Subplot yang ditambahkan bersifat memperjelas dan memperluas pandangan pembaca terhadap plot utama dan mendukung efek keseluruhan cerita (Abrams dalam Nurgiyantoro, 2010:158). Hal itu dapat diartikan pula sebagai gabungan antara alur lurus atau progresif dengan alur sorot balik atau flash-back. Perpaduan tersebut dikarenakan adanya ingatan masa lalu Sutik dan alur sampingan yang melibatkan tokoh-tokoh lain. Nurgiyantoro (2013:211) berpendapat bahwa klimaks dalam novel yang menampilkan cerita yang panjang dapat saja menghadirkan klimaks yang lebih dari satu. Atau dapat saja ditafsirkan adanya adanya lebih dari satu peristiwa yang dapat dianggap sebagai klimaks. Hal tersebut tentu saja sejalan dengan kenyataan bahwa dalam novel sering dimunculkan lebih dari satu konflik. Oleh karena itu, Rodrigues \& Badaczewski (Nurgiyantoro, 2013:211) menggambarkan plot yang mengandung lebih dari satu (kemungkinan) klimaks yang kadar klimaksnya tentu saja berbeda.

Dalam novel $B B M$ terdiri atas tiga bagian besar kisah cerita hidup Sutik. Pada ketiga bagian kisah cerita tersebut masing-masing mengandung tahapan alur mulai dari tahap awal sampai tahap akhir. Oleh karena itu pembagian alur novel $B B M$ akan 
diberikan secara berbeda pada tiga bagian cerita yang dimaksud. Sejelasnya dapat dilihat dalam grafik berikut.

Setelah menjelaskan tentang struktur novel $B B M$ berikutnya adalah menjelaskan citra tokoh Sutik dalam novel tersebut. Kata citra KBBI (2013:160) diartikan sebagai rupa; gambar; gambaran, citra. Citra wanita dalam novel ini berwujud mental spiritual dan tingkah laku keseharian yang terekspresi oleh tokoh Sutik yang memperlihatkan ciri khas perempuan. Saraswati (2003:162) mengemukakan bahwa penekanan teori feminis dalam karya sastra ditekankan pada tokoh cerita yang berjenis kelamin perempuan. Lalu bagaimana kedudukan tokoh tersebut dalam masyarakat, tujuan hidupnya, perilaku serta watak tokoh wanita dari gambaran langsung yang diberikan penulis dan bagaimana pendirian serta ucapan tokoh yang bersangkutan. Berdasarkan apa yang dikemukakan tentang perwujudan citra dalam novel dan bagaimana penekanan teori feminis dalam karya sastra, maka deskripsi tentang citra diri tokoh Sutik dalam Novel BBM akan disingkap dalam tiga kategori yaitu citra Sutik dalam aspek fisik, citra Sutik dalam aspek psikis, dan citra Sutik dalam aspek sosial.

\section{Citra Tokoh Sutik dalam Novel Burung-Burung Migran Karya Miranda Harlan dan Sutik AS \\ Citra Sutik dalam Aspek Fisik}

Penggambaran Sutik dalam aspek fisik tidak banyak diungkapkan dalam novel $B B M$. Deskripsi fisik tokoh Sutik hanya ditampilkan sebagai seorang wanita yang cantik mempesona semenjak kecil. Kecantikannya yang menyeruak menarik banyak orang, bahkan hal tersebut menjadi penyebab Sutik dinodai sewaktu kecil oleh Mbah Tarjo dan guru mengajinya, Mas Mo. Sutik sadar dengan pesona kecantikan yang dimilikinya. Hal tersebut tidak membuat ia menjadi sombong dan lupa diri. Sebisa mungkin ia selalu berupaya sadar untuk memperlakukan kecantikannya bagaikan pisau berbilah dua yang sewaktu-waktu dapat mengangkatnya tinggi-tinggi dan pada saat yang sama menjerumuskannya ke dalam jurang kegelapan. Kutipan berikut menjelaskan pernyataan tersebut.

Kecantikanku telah berkali-kali berkhianat. Ia mengkhianatiku ketika aku masih kanak-kanak, saat aku dinikah siri oleh laki-laki yang kucintai tetapi lebih dulu beristri. Juga, berkali-kali setelah itu, sebelum kita lantas bertemu. Aku tak pernah menyesal sebab ia tak melulu berkhianat, tetapi juga berperan dalam sebagian hidupku yang bisa dibilang enak. Tapi kini, kamu tahu kenapa aku tak tersipu waktu kamu bilang aku cantik. Aku telah terbiasa untuk memperlakukannya, kecantikanku, sebagai makluk yang mesti diwaspadai (Harlan dan Sutik AS, 2011:106-107). 


\section{Citra Sutik dalam Aspek Psikis}

Wanita merupakan seorang manusia yang memiliki pikiran, perasaan, dan kehendak beraspirasi. Demikianlah yang dilihat dalam pandangan psikologi yang juga menempatkan wanita sebagai makhluk psikologi. Keadaan psikis seorang tokoh bagaimanapun turut mempengaruhi citra dirinya. Citra psikis tokoh Sutik dalam novel $B B M$ yaitu berani, peduli, tabah, berjiwa sosial dan kritis dalam menapaki jalan hidupnya.

Dalam novel $B B M$ ditampakkan bagaimana perjalanan hidup yang dilalui Sutik telah membentuk pribadinya menjadi seorang yang mampu merdeka dari penindasan rasa takut dan ragu untuk bertindak seturut keinginan hati. Pernyataan yang mengatakan bahwa kaum wanita adalah kaum lemah yang tidak bisa berdiri tanpa sokongan kaum lelaki, ditepis oleh kenyataan hidup Sutik, seperti pada kutipan berikut. Ketahuilah; ketika aku bercerai, Yamin, aku mesti menjalani hidup yang keras untuk menyuapi anak-anakku dengan nasi dan ilmu pengetahuan. Sebab, bapaknya tak pernah menggenapi tanggung jawabnya sebagai ayah. Aku menjalaninya tanpa mengeluh, tidak juga kuserahkan salah satu atau seluruh mereka kepada Darsono, sebab aku ingin anak-anakku tumbuh kuat dan pintar, dan aku tak bisa percaya pada mantan suamiku (Harlan dan Sutik AS, 2011:39).

Selain citra Sutik sebagai wanita yang tabah, peduli, berani, dan mengasihi sesamanya seperti yang telah dijelaskan, citra Sutik lainnya yaitu sebagai wanita yang kritis. Sebuah fenomena yang mengatakan bahwa citra wanita tidak sepenuhnya adalah makhluk yang patuh saja pada sistem yang pincang. Terlibat aktif dalam gerakan pemberdayaan perempuan bersama sebuah LSM di Jawa Timur, tidak membuatnya diam ketika menyadari adanya ketimpangan-ketimpangan dalam tubuh organisasi yang menaunginya. Sutik mencium adanya gelagat tikus-tikus kantor yang terlibat dalam urusan uang kas daerah. Sutik mengumpulkan bukti-bukti penyelewengan dan menjadi tempat bagi pemuda-pemudi untuk belajar menjadi seorang yang kritis. Hal tersebut terlihat dalam kutipan berikut. Apa-apa itu mesti diselidiki. Supaya kalau ada yang nggak bener, bisa dibenarkan. Jadi orang mesti curiga, kalo nggak ya habis kita dibodohi terus-menerus. Gimana seh, kalian ini diajari orang tua kok nggak nggugu? Candaku (Harlan dan Sutik AS, 2011:286).

Di sisi lain, sebagai seorang wanita, seorang istri yang ditinggal pergi tanpa kepastian kapan akan kembalinya suami tercinta, Sutik sebenarnya juga merupakan seorang wanita yang merana kesepian. Sutik sesungguhnya selalu mendambakan kehadiran Yamin di sisinya. Kerinduan Sutik nampak pada kutipan berikut. Yamin, jika ruang tamu sedang hangat seperti ini, aku kerap mengangankan kamu ada di sini. Menjadi bagian dari kehangatan ini” (Harlan dan Sutik AS, 2011:287). 


\section{Citra Sutik dalam Aspek Sosial}

Tinambunan (2003:27) mengatakan bahwa wanita memiliki karakter mencari dan memiliki hidup dan berusaha untuk berkomunikasi kepada semua orang. Sikapnya tersebut ditunjukkan dengan sikap menghargai, melindungi, memperhatikan, dan memelihara. Wanita dapat dikatakan sebagai makhluk yang dianugerahi untuk memelihara dan mengajar anak-anaknya serta sekaligus dapat memiliki sikap yang sama kepada suami dan siapa saja yang berhubungan dengannya. Citra Sutik dalam bagian ini akan dibagi dalam dua peran yaitu peran wanita dalam keluarga dan peran wanita dalam masyarakat.

Kata "Ibu" dimaknai sebagai kata yang menunjuk pada kodratnya sebagai manusia pelanjut keturunan atau peranannya sebagai seorang wanita yang memiliki anak (Arbain, 2007:87). Kodrat wanita sebagai pelanjut keturunan yakni mengandung, menyusui, merawat dan memberikan kasih sayang pada anak-anaknya (Sukaton dan Munandar dalam Arbain, 2007:87). Setelah dewasa dan jelas saja menjadi seorang Ibu empat anak yang telah bercerai dengan suaminya, Sutik tidak ingin terus merepotkan Emak dan Bapaknya. Setelah resmi menjadi janda, meskipun masih tinggal bersama orang tua, Sutik tetap tampil menjadi tulang punggung bagi keluarga kecilnya. Suami tercinta pergi begitu saja tanpa kabar dan Sutik harus menjadi seorang ayah sekaligus Ibu bagi kelima anaknya. Ada utang besar yang harus dibayar dan orang tua yang baik, tentu saja menyadari bahwa ekonomi keluarga dan masa depan anak-anaknya kini menjadi tanggung jawabnya. Dalam situasi sedemikian rupa, Sutik masih tabah, dan mencoba bertahan segenap hati. Atas dasar rasa sayang, tanggung jawabnya sebagai orang tualah, Sutik akhirnya menyerah pada keputusan untuk berangkat ke Malaysia dan menjadi TKW. Malaysia merupakan negara yang dipilihnya sebab negara itulah yang menjadi belantara keberadaan Yamin. Sutik ingin berjumpa dengan Yamin dan memberitahu Yamin bahwa sudah ada As hasil pernikahan mereka. Selain itu, Sutik tidak ingin As tumbuh tanpa seorang Ayah. Di Malaysia, Sutik sempat hidup ditakdirkan untuk hidup bersama kembali bersama Yamin. Sutik menjalankan kewajibannya sebagai seorang istri Yamin, seperti tidak ada apa-apa sebelumnya. Ketika itu, rasanya seperti tengah membangun sesuatu bersamamu. Perasaan yang nyaris tak pernah kualami sebelumnya, denganmu atau dengan suamiku yang lain. Sepanjang waktu-waktu itu, aku tidak sendirian. Aku bertengkar denganmu. Bersendau gurau. Bekerja sama, layaknya sebuah keluarga. Menyusun masa depan, berebut mimpi tentang As, jika dia besar nanti (Harlan dan Sutik AS, 2011:251). Demikianlah citra Sutik dalam keluarganya. Sutik digambarkan sebagai seorang anak yang patuh pada orang tua, menjadi orang tua yang baik bagi kelima anaknya dan tentu saja merupakan istri yang baik dan setia pada suaminya tercinta. 
Selain citra wanita dalam keluarga yang tercermin melalui tokoh Sutik dalam novel $B B M$, digambarkan pula bagaimana citra sikap sosial Sutik dalam masyarakat. Walgito (Arbain, 2007:96) menjelaskan bahwa sebagai makhluk sosial, wanita pekerja memiliki dorongan untuk berinteraksi dengan lingkungan sosial. Lingkungan sosial yaitu lingkungan masyarakat yang di dalamnya terdapat interaksi individu dengan individu lain. Keberadaan lingkungan sosial tersebut tentu akan berpengaruh terhadap keadaan individu sebagai anggota masyarakat. Wanita memiliki karakter keibuan yang diungkapkan dalam sikap mendampingi; sikap itu ditunjukkan juga dalam membagi-bagikan cara hidupnya kepada sesame manusia, seperti usaha untuk berpartisipasi dalam banyak hal dalam bentuk yang sekecil dan sebesar apa pun. Keibuan ditandai dengan rasa simpatik dan empatik, membangkitkan semangat dan berusaha menggapai prestasi yang lebih tinggi (Stein, 2003:27).

Dalam novel $B B M$ Sutik menjalin relasi yang baik dengan masyarakat. Masyarakat dalam hal ini diartikan sebagai sesama kaum wanita, lawan jenis atau pria, dan masyarakat yang terdiri dari wanita dan pria. Dari tiga macam ikatan yang dijalin Sutik di tengah-tengah masyarakat tersebut. Kesediaannya rela berkorban demi sahabat sesama wanita merupakan sikap sosial yang paling mencuat ditunjukkan Sutik. Salah satu sikap Sutik yang menguatkan pernyataan tersebut yaitu sikap peduli dan bagaimana hubungannya dengan seorang gadis remaja, Sulis, yang terlibat dalam pemberangkatan Sutik menuju Malaysia yang pertama kali. Seperti yang tercantum dalam kutipan berikut. Lapar kini rasanya, setelah dua jam menahan mual di atas kapal tadi. Lagi pula, makan siangku tak seberapa mengenyangkan. Separuh jatahku kan masuk ke perut Sulis. Ah; tapi tak apa. Sekarang aku punya teman seperjalanan. Ini lebih berarti ketimbang sekedar perut kenyang (Harlan dan Sutik AS 2011:77).

\section{KESIMPULAN}

Berdasarkan hasil penjelasan tentang citra tokoh Sutik dalam novel Burung-Burung Migran karya Miranda Harlan dan Sutik AS: kajian perspektif feminisme dapat ditarik beberapa simpulan:

1. Berdasarkan analisis struktur novel, pada analisis latar dan pelataran, terdapat tiga jenis latar yang ditemukan yaitu latar tempat, latar waktu, dan latar sosial. Latar tempat dalam novel $B B M$ mencakup nama negara dan daerah yaitu Malaysia, Tretes, Singapura, Surabaya, Andalas dan Pinang. Latar waktu dalam novel tersebut dijelaskan dengan menyebutkan momen hidup Sutik tanpa kejelasan penyebutan tahun, dan deskripsi latar waktu yang langsung menyebutkan tahun, bulan dan tanggal. Adapun latar sosial yang ditemukan dalam novel $B B M$ dibagi berkaitan dengan prilaku, pola pikir, kebiasaan masyarakat pada tempat-tempat yang dikunjungi Sutik yaitu masyarakat desa 
Prigen, Tretes, kawan serombongan TKW Sutik, masyarakat Malaysia yang terdiri atas para majikan dan polisi penjaga penjara wanita, masyarakat TKW Indonesia di Malaysia, dan anggota perkumpulan wanita PSK. Terdapat 11 tokoh penting dari 55 tokoh yang dilibatkan dalam novel BBM. Sebelas tokoh yang dimaksud adalah Sutik, Yamin, Sulis, Mbah Tarjo dan Pak Mo, Chow dan Tessa, Sumiati, Bang Man, Tuti, serta Milah. Alur dalam novel BBM menggunakan alur maju-mundur. Novel $B B M$ mengandung empat klimaks dengan tingkatan yang berbeda.

2. Berdasarkan analisis citra tokoh Sutik dalam perspektif feminisme, tokoh Sutik dalam novel $B B M$ digambarkan dalam tiga aspek yaitu dari aspek fisik, aspek psikologis dan sosial. Dalam aspek fisik, Sutik digambarkan sebagai seorang wanita yang cantik. Dalam aspek psikis, singkatnya Sutik merupakan seorang wanita yang berani, tabah, peduli, penuh kasih sayang, kritis. Dalam aspek sosial, Sutik berperan sebagai Ibu yang baik dan penyayang bagi anak-anaknya, menjadi istri yang tetap setia mencintai suaminya.

Beberapa saran yang diutarakan setelah melakukan penelitian ini yaitu sebagai berikut: (1) Novel BBM karya Miranda Harlan dan Sutik AS merupakan jenis novel biografis yang dapat menginspirasi siapa saja untuk berani "merdeka" dari rasa takut, sehingga dapat bertindak sesuai keinginan hati. Hal tersebut boleh jadi amanat yang dapat dipetik dari novel $B B M$ yang tentu saja dapat dimanfaatkan oleh para guru bahasa dan sastra Indonesia dalam rangka menunjang pembelajaran sastra Indonesia di sekolah serta berguna bagi pendidikan akhlak peserta didik. (2) Novel BBM dapat juga dianalisis dalam perspektif feminisme dalam kaitannya dengan wanita sebagai penulis novel atau yang bisa disebut kritik sastra ginokritik. Hal tersebut dikarenakan penulis novel tersebut adalah Miranda Harlan dan Sutik AS yang dua-duanya adalah wanita. (3) untuk penelitian serupa selanjutnya disarankan untuk secara cermat dalam mengenali novel yang akan dijadikan sebagai rujukan terlebih dahulu, dan giat dalam menemukan kepustakaan yang mendukung pengkajian novel.

\section{DAFTAR PUSTAKA}

Aminuddin. 2010. Pengantar Apresiasi Sastra. Bandung: Sinar Baru Algensindo. Harlan, Miranda dan Sutik As. 2011.Burung-Burung Migran.Jakarta: Qanita. Karolus, Meike Lusye. 2013. Feminisme dalam Dongeng. Yogyakarta: Graha Ilmu. Kennissa.29April,2013.(online),(https://kennissabaca.wordpress.com/2013/04/29/bur ung-burung-migran/, diunduh 24 April 2015).

Muhammad K.S., Rais.14 November, 2012. Resensi Novel Burung-Burung Migran. Karya Miranda Harlan dan Sutik A.S.(online), (https://mkksmojokerto.wordpress.com/2012/11/14/resensi-novel/, diunduh 23 April 2015). 
Nelwan, Iisa dan Gail Maria Hardy. 1998. Perempuan dan Politik Tubuh Fantastis. Yogyakarta: Kanisius.

Nurgiyantoro, Burhan. 2010. Teori Pengkajian Fiksi. Yogyakarta: Gadjah Mada University Press. 2013. Teori Pengkajian Fiksi. Yogyakarta: Gadjah Mada University Press.

Ratna, Nyoman Kutha. 2010. Teori, Metode, dan Teknik Penelitian Sastra. Yogyakarta: Pustaka Pelajar.

Rini, Ajeng Mega Listia, Martono, Sesilia Seli. (tt). Citra Perempuan dalam Novel Hati Sinden Karya Dwi Rahyuningsih (Kajian Feminisme

Marxis).(online),(http://download.portalgaruda.org/article.php?article $=158167 \& \mathrm{val}=$ 2338\& title $=$ citra\%20perempuan $\% 20$ pada $\% 20$ novel $\% 20$ hati $\% 20 \operatorname{sinden} \% 20$ karya $\% 20$ dwi\%20rahyuningsih\%20(KAJIAN\%20FEMINISME\%20MARXIS, diunduh 23 April 2015).

Rokhmansyah, Alfian. 2014. Studi Dan Pengkajian Sastra (Perkenalan Awal Terhadap Ilmu Sastra). Yogyakarta: Graha Ilmu.

Saraswati, Ekarini. 2003. Sosiologi Sastra: Sebuah Pemahaman Awal. Malang: Bayu Media dan UMM Press.

Srinth! Media Perempuan Multikultural. 2005. Perempuan dan Sastra Postkolonial. Depok: Kajian Perempuan Desantara. Vol. 8:115.

Sugihastuti. 2009. Teori Apresiasi Sastra. Yogyakarta: Pustaka Pelajar.

Tinambunan, Edison. R.L. 2003. Perempuan Menurut Pandangan Edith Stein. Malang: Dioma.

Tim Pustaka Phoenix. 2013. Kamus Besar Bahasa Indonesia Edisi Baru. Jakarta: Media Pusataka Phoenix.

Ummu Hanie. 2012. Tokoh dan Penokohan dalam Novel Hikayat Zahra Karya Hanan Al-Shaykh. (online), (http://lib.ui.ac.id/file?file=digital/20308403-S42512Tokoh\%20dan.pdf, diunduh 18 April 2015).

Wiyatmi. 2005. Pengantar Kajian sastra. Yogyakarta: Pustaka.

Yuliastuti, Fitri. 2005. Citra Perempuan dalam Novel Hayuri Karya Maria Eti. (online), (http://eprints.uns.ac.id/5594/1/69632406200905461.pdf, diunduh 23 April 2015). 